\title{
A terminological study about university-society relations: third mission, socioeconomic surroundings and the evolution of the role of academia
}

\author{
Ana Maria Nunes Gimenez \\ Postdoctoral research fellow in the Department of Science and Technology Policy at the University of \\ Campinas (DPCT/IG/UNICAMP), with grant from the National Postdoctoral Program (CAPES/BRAZIL) \\ by the National Institute of Science and Technology in Public Policy, Strategies and Development - \\ INCT/PPED. E-mail: anamarianunesgimenez@gmail.com
}

Maria Beatriz Machado Bonacelli

Associate professor at the Graduate Program in Science and Technology Policy at the University of Campinas (DPCT/IG/UNICAMP). E-mail: biabona@unicamp.br

\begin{abstract}
The relationships and interactions between universities and society that go beyond the teaching and research missions have been termed differently by various groups of scholars and in different countries and are more commonly known by the term "university extension". The different views and interpretations of university missions relate to the development of the understanding of the role of this institution in society. In respect to this, the purpose of the article was to present, based on extensive literature review, the conceptualization of the main terms commonly used to express the university-society relations: third mission, outreach, extension, vinculación, engagementcommunity and civic. The research results allow us to conclude that the terms studied arise from very similar situations and purposes, namely: teaching and research missions and responsibilities of the university vis-à-vis new visions of the social pact or contract between academia, science and society.
\end{abstract}

Keywords: university and community; third mission; knowledge transfer; extension; science, technology and society

\section{Introduction}

The university of the twenty-first century has been pressed to reconsider its ways of acting with a view to the development of more intense and lasting interactions with the various sectors of society, in a process of opening to and immersion in its surroundings, abandoning what some scholars have termed "ivory tower" status. This term has been used since the 19th century to designate not only a posture but also an institutional environment in which teaching and research activities are disconnected from the needs and concerns of society (European Indicators and Ranking Methodology for University Third Mission - E3M, 2012a).

From the twentieth century on, there have been profound changes in the modus operandi of universities, not only due to the takeover of the research mission and the steady increase in scientific activities, but also due to the volume of resources destined to their funding, increasingly creating the need of support from their donors, i.e., society. Thus, the public support of university research has increasingly depended on the relevance of the social "pact" or "contract" signed between academic science and society. This relevance is related both to a cultural enrichment and a better understanding of the world, namely, the extension and sharing of knowledge to society, but, also, to a conduct of research that meets the 
needs and demands of society and even to contributions to economic competitiveness (Hessels, Van Lente, and Smits, 2009), especially as a result of public funding. "A 'pact' is a fairly long-term cultural commitment to and from the University, as an institution with its own foundational rules of appropriate practices, causal and normative beliefs, and resources, yet validated by the political and social system in which the University is embedded." (Gornitzka et al, 2007, p. 7).

In face of these contextual changes and new understandings about the role of scientific institutions in society, the importance of the involvement of higher education institutions (HEIs), especially research-intensive universities, in their surroundings and in society in general has grown, with such institutions contributing more actively to social and economic development, becoming protagonists and key actors of the National Innovation Systems. Moving beyond, the development of more intense and lasting relations between the University and society, in addition to the teaching and research missions, has been the focus of discussions of several actors, among them scholars, policy makers, governments, institutions leaders, members of the academic community, and others around the world. It is in this context of discussions that the concept of third mission has gained prominence, understood as an external commitment to socialize and share experiences, expertise, and other capabilities that universities have, in a process of immersion, engagement and attention to their surroundings and to the most pressing needs and demands of the societies that sponsor them.

It can be argued that these views on the different and multiple forms of university-society relations are linked to the term "multiversity" - used by Clark Kerr in 1963 - as a counterpoint to the term university, since the institution has taken on increasingly diverse roles and has been linked to different publics, distancing itself considerably from the original community of masters and pupils of the Middle Ages. The "multiversity" no longer has a single purpose, or it shouldn't have; it requires dealing with a multitude of conflicts and redefining its limits; it cannot be static in a dynamic world and it cannot be intolerant in a world that lacks understanding. It is a complex and multifunctional institution, consisting of several communities (of humanists, social scientists, hard sciences, technological areas and other areas, the administrative staff, the administrators) and with imprecise borders or boundaries, because it reaches or interacts with, in greater or lesser degree, several external groups (alumni, policymakers, legislators, government agencies, entrepreneurs from various sectors, farmers, among other groups) (Kerr, 2005).

However, Venditti, Reale and Leydesdorff (2013) warn that the vast majority of research and studies concerning the third mission has focused on examples of "good practices" of American institutions, such as the Massachusetts Institute of Technology (MIT) and Stanford University, as well as some European universities, all in the field of technology transfer, but this attitude only serves to strengthen the understanding of the real contribution of the third mission to society. Thus, the idea of a third mission, as Görason, Maharajh and Schmoch (2009) see it, expresses an understanding for a more 
active and visible role of the university in society and should serve to stimulate and guide the use of knowledge for the promotion of social, economic and cultural development.

It can be seen, therefore, that the involvement in third mission activities goes beyond the contribution to the capacity to innovate, assuming a much more comprehensive character. One must, then, have in mind that the discussion on the scope and coverage of the third mission varies considerably between countries and in different contexts. It is our understanding that a lack of comprehension, along with narrow mindsets, can hamper the formulation, implementation, and management of policies, programs and practices related to the third mission, as well as limit the design of the university as a socially active agent, hence the relevance of this research.

As a result of these findings, this article seeks to investigate concepts and practices related to the multi-faceted universitysociety interface, with focus on the concept and scope of the third mission. Based on a large bibliographical and documentary study, we have identified recurrent terms that have integrated the nomenclature commonly used in different countries to name the relations and interactions that result from the accomplishment of teaching and research missions and that are destined to extend the knowledge produced internally to society. We elected a conceptual framework of the main discussions that have been developed on the topic of "university-society relations." To this end, we favored a broad and inclusive approach, i.e., one which is not exclusively focused on university-industry relations, but which starts from a broader perspective in order to consider the various possibilities of interaction between universities and the rest of society, interactions that go beyond technology transfer activities, without, however, disregarding them. The terms in question are: third mission; extensão (in the Portuguese language), outreach (term in English); extensión and vinculación (in Spanish); we also noted that the use of the term engagement has grown. The main goal of this study, therefore, is to explore this terminological variety so as to determine the evolution of understandings about university-society relations, through the emergence of new social demands and missions, as well as to identify the differences, similarities, points of contacts or conceptual convergence between terms.

This work is exploratory and descriptive in its purpose and the approach adopted was qualitative, stemming from a literature review based on bibliographical material of interdisciplinary nature. The university-society relationship is called here third mission (considering teaching the first mission and research the second). It is important to mention that the literature commonly refers to teaching and research as being the initial missions, taking into consideration the origins and development of universities over time. While teaching represented its primeval purpose, research was only instituted as a university mission in the nineteenth century, with the creation of the University of Berlin (1809/1810). According to Allen (1988), mission means the basic purpose of a university, its raison d'être.

Therefore, this work presents the results of the exploratory and qualitative research through which we sought to understand the various ways of naming the relations of higher education, more specifically, universities, with society. 
countries and continents we found that there are different ways to name and understand the relationship between university and society in addition to teaching and research activities, which motivated us to explore this conceptual variety. Based on extensive literature review, the following conceptualization terms were identified and selected: (i) engagement - community engagement, public engagement, social engagement and civic engagement; (ii) third mission; (iii) outreach; (v) extension (extensión); (v) vinculación.

The aforementioned are terms that, much beyond naming postures, strategies and specific policies - namely, the various actions and practices that act as a bridge between education, research, dissemination and sharing of knowledge and experience beyond the walls of the university - also express different views about the relevance and legitimacy of some of these actions.

Concepts are meaningful expressions or terms that exhibit a complex history, full of social action. They help delimit and locate the subject they aim to understand. One can infer, then, that the process of conceptualization must consider the surrounding reality, as well as the contextual changes through which the object of analysis has been, so as not to be a mere lexical activity (Minayo, 2009). Thus, the study of concepts helps in apprehending the evolution of understanding on our research subject: university-society relations. It is worth noting, however, that although it is important to understand, contextualize and discuss the actions and role of educational institutions in society, taxonomies should not be dictated or imposed, but they should represent and describe the ways through which universities relate to the world, from a non-reductionist view on their possibilities of action (Clough, 2009; E3M, 2012b).

It is also important to clarify that, in this work, we use the term "community" to represent groups or specific social actors, such as corporations, governments, civil society organizations and other associations, among others. According to Jongbloed, Enders and Salerno (2008), communities can belong to different levels: closer - local and regional - or more distant - national, international. Each higher education institution (HEI) will define the communities with which they intend to have an interface with and this will depend on their physical capacities and knowledge, their size, the volume of resources available for such purposes, as well as the specific demands and needs of each locality.

The term "surrounding" refers to the relationships that universities and other HEIs keep, or could keep, within their closest vicinity: their neighborhoods, their cities, their regions. Finally, the term "society" is used to represent the set of all the previously mentioned social ecosystems (E3M, 2012b). Therefore, university-society relations, in addition to the teaching and research missions, involve any links with the outside world, be it with companies or with non-profit organizations, neighborhood associations, policy makers, and several other social actors.

In addition to this introduction, this work is comprised of three more sections: the second one presents a panorama, not exhaustive, of the development of the third mission, starting from the first experiences with university extension up to involvement with entrepreneurship, innovation, technology transfer and engagement with local/regional demands; the 
third section features an analysis of the evolution of different ways of naming and understanding university-society relations, by means of a terminological and conceptual study; finally, in the fourth section, the results of the research are briefly discussed and the final conclusions are drawn. The results allow us to conclude that the different ways of naming and understanding university-society relations represent the evolution of the understanding on how the infrastructural and knowledge capacities of universities can reach audiences that are external to the academic community.

\section{Third Mission: a Brief History from Selected Milestones}

Several scholars claim that the idea of a third mission arose in the nineteenth century at the University of Oxford, from 1840/1850, and at the University of Cambridge, circa 1873, when they established the foundations for what today is called university extension with extramural activities. Mackinder and Sadler (1891) affirm that the term 'extension' began to be used circa 1845, at the University of Oxford, becoming of general use in subsequent years. The movement for extension originated with the displacement of some faculty members of these two universities to the heartland of England, to minister lectures in places where there was no access to university knowledge.

At the University of Cambridge, for example, in the second half of the nineteenth century (between 1867 and 1873), proposals were approved for the organization of courses and lectures to be taken to institutes of mechanics, cooperatives, schools and other associations, especially in the north of England, laying the foundations for future schools or university extension and adult education departments, not only in Britain but throughout the world (Welch, 1973). It is estimated that, in 1891, England already had more than 80,000 extension students (American Society for the Extension of University Teaching, 1891). According to Maunder (1972), the first transfers of public funds for extension activities were directed to lectures on agriculture. In 1903, the Workers' Educational Association (WEA) was created to provide part-time educational opportunities to workers from England and Scotland, as well as to implement programs of involvement with communities. This initiative was one of the major changes the British extension movement has undergone.

The Industrial revolution triggered different types of needs within the English industrial towns; scientific knowledge would assist in the search for solutions to the growing problems of industrial production on a large scale in the nineteenth century. This new reality led to the creation of another type of university, the 'civic universities'. Such institutions should promote the integration between teaching, research and local socioeconomic development by connecting to their communities, presenting themselves as an alternative to the Oxbridge model (the junction of Oxford and Cambridge), which was elitist and closed (Barnes, 1996).

The connections of these universities with their socioeconomic surroundings were numerous, including the following: training of skilled labor for the industries, support to industries through scientific advice etc. (Goddard, Kempton, \& Vallance, 2013). However, Fallis (2004) explains that Scottish universities, unlike Oxford and Cambridge, have always 
been more open and connected with their surroundings, especially after the Scottish Reformation (from the sixteenth century), maintaining ties with governments and local councils, enhancing social mobility and the idea of serving society.

In the United States, extension was developed mainly under inspiration of the English experience, although it has differed and developed by adopting characteristics of its own. In 1890, the American Society for the Extension of University Teaching, in Philadelphia, was created, with the purposes of producing knowledge about extension, designing extension activities and cooperating with educational institutions and other organizations in this field. The University of Chicago was the first to create an extension division, in 1892, comprised of six departments, each with its own assignment (lectures, weekend courses, evening courses, study classes, off-campus courses similar to those offered regularly by the university, etc.) (University of Chicago Library, 2006). University extension, in its service-provision modality, came up with the land grant movement in the United States, and the Land-Grant Colleges were the precursors. The donation of 30,000 acres of federal lands for the purpose of financing public universities in the American states - although private universities were also financed - was authorized by two federal laws, the Morrill Acts of 1862 and 1890, especially for the promotion of agricultural and industrial development (Library of Congress, 2016; United States of America, 1862). Kerr (2005) highlights the importance of the land grant movement for the access of students from less privileged classes to higher education, democratizing access to tertiary education, in addition to it having been an important milestone for the creation of agencies for the provision of services and experimental agricultural stations. It is worth noting that the American extension model, in its rural extension modality, exerted great influence over Latin American countries, including Brazil, where the higher schools of Lavras (1921) and of Viçosa (1929), in the state of Minas Gerais, were created to provide technical assistance to farmers (Rocha, 2001).

In Latin America, discussions favoring a more inclusive and open university emerged in Argentina in 1918, with a reform movement based on the aspirations of students at the University of Cordoba, in reaction to a university they perceived as an oligarchic 'ivory tower', alien to society (Bernasconi, 2008). However, even with the expansion of reformist ideals in Latin America, the concept of extension that prevailed over several decades was that of delivery, of cultural dissemination, which sees the community only as a recipient, in a unidirectional and uncritical movement. In addition, there were no structured programs with well-defined objectives; extension practically remained in the margin of the other university missions, with almost none, or no relation whatsoever, with teaching and research; lecturers showed no interest in its development, and there was little projection in the communities. This paternalistic, patronizing perspective would only be questioned in the 1970s, with the second Latin American Extension Conference, held in Mexico, organized by the Union of Latin American Universities (UDUAL), in 1972 (Bernheim, 1978).

The involvement of universities with entrepreneurial activities, in turn, began in the United States, in the mid-twentieth century, when academic lecturers and professors began to engage with entrepreneurship, innovation and technology transfer activities, technology parks, among others, with the Massachusetts Institute of Technology (MIT) and Stanford University 
serving as paradigm. From then on, gradually, the university started to be considered a relevant actor for economic and social progress and an important actor of the National Innovation Systems.

Burton R. Clark was one of the first authors to use the term 'entrepreneurial university', in the 1998 book 'Creating entrepreneurial universities: organisational pathways of transformation', in which he presented the results of research carried out in five universities: Warwick, in England, Twente, in the Netherlands, Strathclyde, in Scotland, Chalmers, in Sweden, and Joensuu, in Finland. According to Clark (1998), entrepreneurial university is the one that performs modifications in its structure and organizational culture to become more proactive, flexible and dynamic in the management of its relations to the economy and society. Another approach, the Triple Helix, emphasizes the university-industry-government interaction, considering the university as a centerpiece of the knowledge-based society and one which can strengthen, increasingly, its role in the process of innovation, capitalizing knowledge and contributing to economic and social development (Etzkowitz \& Leydesdorff, 1997).

In Latin America, universities have traditionally focused more on the education mission, while the development of scientific and technological skills and processes of knowledge transfer to the productive sector were relegated to the background. Facing this reality, in general terms, the ties between academia and industry are still weak, as are the possibilities for an effective contribution to economic development (Scoponi, Dias, Pesce, Schmidt \& Gzain, 2016). Notwithstanding, some authors deem it important to consider that the delimitation of the field of action and of the activities that should be included in the definition of the third mission vary considerably between countries and in different contexts. Göransson, Maharajh and Schmoch (2009, p. 158) observe that

the international debate on third mission is largely dominated by the paradigm of the United States, where spin-off enterprises from universities in biotechnology and information technology implied a real economic boom. (...) Many countries introduced similar legislation to support university patents. The question may be asked whether these models can be transferred to other countries, or indeed if they are relevant at all, in particular to developing and transition economies.

Moreover, in the twenty-first century, knowledge centers are expected to play a more active role in their regions through the development of a regional mission. By regional mission we mean the opening of universities to the regions where they are located and their involvement with specific demands and needs, which can result in a wide range of implications and interactions, of cultural, social and economic nature (Arbo \& Benneworth, 2007). The regional mission has gradually become understood as a strategic opportunity to support the adoption of an identity and an institutional profile, dissociating itself from the idea of a mere moral obligation to allocate scarce resources (Pinheiro, 2011).

Grau (2014) proposes that universities should worry about their surroundings as much as about their internationalization, through the development of a 'Glocal' University, which is one that promotes interaction between a global vision and local 
impacts of its activities. It is important to consider that even in the network society era, whose main feature is its global nature, 'most of human experience is local, both in cultural and territorial terms' (Castells, 2009, p. 25). Thus, the development of the third mission represents an attempt to change the way universities are embedded in their communities and regions (Venditti et al., 2013).

\section{Conceptualizing and Understanding University-Society Relations}

\subsection{Engagement: the engaged university}

The Kellogg Commission on the Future of State and Land-Grant Universities, in the report entitled 'Returning to our roots: the engaged institution', states that the 'by engagement, we refer to institutions that have redesigned their teaching, research, and extension and service functions to become even more sympathetically and productively involved with their communities' (Kellogg Commission on the Future of State and Land-Grant Universities, 1999, p. 9). According to BHERT (2006, pp. 3-4):

communities engagement' has a broad vista that extends beyond business and economic aspects. [...] Engagement is a characteristic of a university's policy and practice and is reflected in the responsibilities given to senior staff, rewards and incentive mechanisms, career structure and promotion criteria, the learning experience of students and the number, nature and sustainability of relationships with organisations external to it. Engagement should also have a two-way orientation, with institutions outside higher education committed to interactions with universities in a similar way.

The report 'Characterising modes of university engagement with wider society: a literature review and survey of best practice', prepared by Conway, Humphrey, Benneworth, Charles and Younger (2009) for Newcastle University, stated that they 'use a very wide definition of the term 'engagement' in this report, to refer to all the relationships and connections which universities have with the wider society, including businesses, government, the voluntary and community sector and other societal actors' (p. 2). Thus, engagement occurs not only through an overflow of fundamental university activities, such as teaching and research, but it has increasingly become an institutional mission in and of itself.

In a project on the third mission (sponsored by the European Commission), 'European Indicators and Ranking Methodology for University Third Mission', the term engagement was used to give the idea of a social purpose for universities and the ability to transform the process of driving the third mission into a synergic path comprised of discussion, co-creation and mutual learning (E3M, 2012b). 'Social engagement is usually related to ties of mutual benefit at a local level, between university members and communities within its home city and region’ (E3M, 2012b, p. 6). 
In 2006, the Carnegie Foundation created an elective classification, called 'Community Engagement Classification', which assesses the level of engagement of HEIs with their communities. Thus, according Carnegie Foundation for the Advancement of Teaching (2013, p. 2), the term community engagement:

Describes activities that are undertaken with community members. In reciprocal partnerships, there are collaborative community-campus definitions of problems, solutions, and measures of success. Community engagement requires processes in which academics recognize, respect, and value the knowledge, perspectives, and resources of community partners and that are designed to serve a public purpose, building the capacity of individuals, groups, and organizations involved to understand and collaboratively address issues of public concern.

Bringle, Hatcher and Holland (2007, p. 15) explain that civic engagement is an 'active collaboration that builds on the resources, skills, expertise and knowledge of the campus and community to improve the quality of life in communities', in terms of education, research and services. Nowadays, the idea of public service aimed at the common good has forced higher education institutions to take on a new type of commitment, having to rethink their epistemologies, structures and pedagogies, to integrate teaching, research and services missions in this commitment (Fitzgerald, Bruns, Sonka, Furco, \& Swanson, 2012).

\subsection{Outreach}

Bringle et al. (2007, p. 15) understand that the concept of outreach is the following:

The application of knowledge and provision of services to the community. Activities that extend knowledge in the academy to the public through a variety of mechanisms which may be active (e.g., continuing education, extension services, public information programs, radio/television broadcasts) or passive (e.g., athletic programs, cultural events, library services, publications).

In the context of the UNESCO Chair in Community-based Research and Social Responsibility in Higher Education, the 'Manual on Institutionalizing Community University Research Partnerships: a user's manual' was created. It stated that it was during the 1990s that many universities began to use the term outreach to represent activities developed with outside public, but the term has been revised because it conveys the idea of simple communication and delivery of services and knowledge, not necessarily sharing and reciprocity. The manual also differentiated the outreach/extension of community engagement as follows: (i) outreach/extension brings the idea of passive citizens; it does not involve alliances, partnerships or significant co-production of knowledge; (ii) community engagement encourages proactive and empowering citizens; it assumes doubly beneficial involvement through partnerships, alliances, sharing and co-production of knowledge (PRIA and University of Victoria, 2015). 


\subsection{Third mission}

Roper and Hirth (2005) explain that, in the US, the third mission evolved from the traditional conception of services through a vision of the university as capitalizing knowledge (especially driven by the Bayh-Dole Act, from 1980) and contributing to economic development, to a new view on the role of the university in the twenty-first century, the university engaged with its communities. Conway et al. (2009) explain that the debate around a third mission of higher education institutions was intensified in the 1980s, when there was a heightened understanding that this mission would cover both interactions with companies and the valuation of intellectual property, but also a greater engagement in interactions with small and mediumsized enterprises, marginalized communities, non-governmental organizations, among other actors.

Teixeira (2015) mentions that there many universities around the world show a growing interest in more openness and integration to their surroundings, explaining that this is due to the knowledge economy and the identification of social demands. Thus, University Extension has gained an ever-growing importance, both in Latin America (where its main focus is direct social actions and interventions that promote citizenship and leadership) and in developed countries (focused on services and technology transfer). According to the author, "third mission" is the most widely used correlate term to extension in Continental Europe.

In the literature, the entrepreneurial university emerged as a way of achieving the third mission, which set the university as the driving force of the economy (Trencher, Yarime, McCormick, Doll \& Kraines, 2014). In the present day, however, it is understood that third mission and entrepreneurial university are not synonymous expressions; on the contrary, as the first is much broader and involves social and economic dimensions, while the second one expresses only an economic dimensionalthough much of the literature usually focuses on the latter (Inzelt et al., 2006). Thus, the idea of the entrepreneurial university, from the point of view of an organizational approach (Burton Clark) or the Triple Helix model (Henry Etzkowitz \& Loet Leydesdorff), represents a specific dimension of engagement, generally more strongly linked to the economic development strand.

In the context of the 'European Indicators and Ranking Methodology for University Third Mission” (E3M), for example, the third mission was composed of three dimensions, by convention: (i) continuing education; (ii) technology transfer and innovation; and (iii) social commitment.

Molas-Gallart and Castro-Martínez (2007) state the following in the paper titled 'Ambiguity and conflict in the development of 'Third Mission' indicators': 'We use the term 'Third Mission' to refer to all activities concerned with the generation, use, application and exploitation of knowledge and other university capabilities outside academic environments' (p. 321), following the understanding of Molas-Gallart, Salter, Patel, Scott and Duran (2002). However, Molas-Gallart and CastroMartínez (2007) also mention that there are still many differences over the possible interpretations and the scope of the third mission. For some, the third mission is an additional source of income, for others it is the commercial exploitation of the 
results of academic research, and there are yet those who understand it to be the social impact of universities. In the latter case, the authors cite the example of Latin American universities, which have their offices or extension schools, by means of which they connect to society.

In a project called VINCULAENTORNO, co-financed by the European Commission and which also featured the participation of Latin American universities, it was stated that the development of the third mission is advantageous because it contributed to a greater involvement of higher education with society, strengthening and enriching the traditional missions (teaching and research), urging academics to pay attention to social needs, generate new ideas, create business opportunities and jobs, among other contributions (Mora \& Vieira, 2014).

A report ${ }^{1}$ commissioned by the Higher Education Funding Council for England (HEFCE), stated the following: "terms such as 'knowledge transfer/exchange', 'enterprise', 'outreach' or 'engagement' are more commonly used in the higher education (HE) sector and in Government" (PACEC \& CBR, 2009, p. 1). In addition, for the HEFCE:

the term 'third stream' refers to interactions between HEIs and external organisations in the private, public and voluntary sectors, and wider society. It assumes that some knowledge or expertise flows between HEIs and users through these interactions (PACEC \& CBR, 2009, p. 1).

Conway et al. (2009) comment that the first third stream experiences were directed to financing of knowledge transfer activities and technologies for businesses. However, successive policies in this field have led to several additions of third stream activities, including broader relationships with the community at large, according to analyses carried out by the Centre for Business Research, University of Cambridge (CBR) and the Public and Corporate Economic Consultants (PACEC), commissioned by HEFCE, widening the range of activities. Currently, hence, third stream involves relationships with companies, business organizations and the community, maintaining close relationship with the expertise of HEIs in the field of teaching and research, and consistent with the infrastructure of each institution.

Therefore, taking into consideration the authors that have been mentioned here, it is possible to understand that the two expressions, third mission and third stream, have been currently used to represent interactions, exchanges, involvements of the university with actors outside the academy, converging to the same purposes, namely: connecting knowledge and expertise of universities to society, which is increasingly seen as a mission of the university. The emphasis on relations, either with the industry or with communities, to revenue-raising or not, will depend on the choices that an institution makes. However, it is worth noting that the term third stream has been used in some studies with an economic connotation, i.e., as a way of obtaining resources.

\footnotetext{
${ }^{1}$ Report title: "Evaluation of the effectiveness and role of HEFCE/OSI third stream funding. Issues Paper 2009/15 for HEFCE".
} 


\subsection{Extension and vinculación}

Fernández-Larrea and González (2013) believe that university extension is the most objective and complete term to name university-society relations, claiming that it involves, among others, cultural diffusion, social action, projection and social interaction. The authors also believe that extension is the most appropriate term because of its historical character, since it was the first manifestation of social action by the university, and also because it identifies more deeply with transformative actions. According to them, Latin American universities have adopted their private third mission for many decades, an extension plan that is different, in many respects, to the ones seen in developed countries.

For Serna Alcántara (2007), the social mission of the university, that is, its responsibility to promote and coordinate actions of culture and knowledge sharing with the poorest and least educated members of society and then promote social justice, was attributed to university extension. Thus, university extension is considered the forerunner of the involvement of universities with the environment that is around it, i.e., its surroundings, communities, or, in broader terms, with society.

In the "Documento de base para un 'Manual de Indicadores de Vinculación de la universidad con el entorno socioeconómico' - Manual de Valencia", D'este, Castro-Martinez and Molas-Gallart (2014) mention that the term third mission was employed with the same meaning of vinculación (here translated as linkage), because, according to the authors, the first is much broader and involves all the activities and relationships of the university with its surroundings. However, the authors recognize that there is no consensus regarding its use.

In the Manual de Valencia (2017), prepared by the Ibero-American Observatory of Science, Technology and Society (OCTS-OEI) and the Ibero-American network of Science and technology indicators (RICYT), it was assumed that vinculación activities are the following:

a) knowledge generation and the development of collaborative capabilities with non-academic agents and drafting of legal and cultural landmarks that guide the opening of universities to their surroundings; b) the use, application and exploitation of knowledge and other existing capacities of the university outside the academic environment, as well as training, services supply, advising and consultancy, conducted by universities in their surroundings (OCTS-OEI \& RICYT, 2017, p. 11).

In Latin America, there is preference for the use of the term university extension (in the first place), while vinculación (linkage) to the environment or to society is usually the second most used term. Third mission, on the other hand, tends to be rarely used. However, it is understood that the three terms - third mission, extension and vinculación (linkage) - have common aspects, namely, putting the knowledge that is generated in the universities at the service of society, as well as collaborating with surrounding agents, which constitute a specific mission of Latin American universities (Grao, Iriarte, Ochoa, \& Vieira, 2014). 
According to Grao et al. (2014), in Latin America, the extension has a different connotation in relation to the third mission approaches of developed countries, since preferences for cultural dissemination activities and social services directed to disadvantaged groups are predominant. They affirm that the traditional concept of extension has been diluted due to specific demands of a present knowledge society, which include the incorporation of innovation, social inclusion and internationalization. Also, although some academic sectors are reluctant to accept the involvement of Latin American universities with the productive sector, the authors mention that the concept of extension is connected, nowadays, to the third mission, with the aim to guide the transfer of knowledge to society, which would lead to the problems and demands of both universities and society being handled and solved jointly, by means of an entrepreneurial, innovation-focused stance.

\section{Discussions and Conclusions}

The results allow us to conclude that, although university-society relations are understood and named in different ways, it is possible to affirm that the terminology studied expresses a set of very similar purposes for the avant-garde universities, i.e., those that are ahead of their time, varying only with regard to emphasis and range of purposes. Thus, among the goals or purposes identified in the different terms that were studied, there are the following: reaching audiences that are external to the academic environment; sharing/disseminating university knowledge to society; providing services; obtaining financial resources; offering artistic and cultural activities and recreation; promoting socio-economic development; among others. In this sense, the meanings are similar, which makes it possible to affirm that we are much closer to a synonymy than antonymy between these different terms.

Relationships with society have been diverse, representing an advancement of the understanding of the role of universities in society. There have been attempts to overcome paternalistic attitudes and one-way transmissions of knowledge and delivery of services, moving towards more complex interactions, through sharing and co-production of knowledge, skills and experience. It should be noted that these challenges are a global phenomenon and solutions cannot be universal; rather, each country, each region, each university must find the models that best fit its reality and its purposes. These purposes may vary in scope and this is intrinsically linked to the characteristics of each university (for instance, whether the emphasis is on teaching rather than research, or both); to human and financial resources; and to the infrastructure that each institution has (laboratories, museums, libraries, among others).

In Latin America, there is a well-established tradition of developing university extension, which is deemed the strongest link between Latin American universities and society. Due to the specific characteristics of the region, activities aimed at the disadvantaged, along with cultural diffusion, have historically occupied a prominent place in the developmental preferences of extension. Vinculación is the term that has been used in some Spanish-speaking countries instead of university extension, on the idea that it depicts more intense and collaborative commitments. In Brazil, for example, certain types of relationships are not well-seen by some sectors within the universities, who see them as stemming from utilitarian attitudes that interfere with the purity of principles and ideals that they view as absolute and inviolable - autonomy and freedom to define research 
agendas. From this perspective, the involvement with external demands, especially of the productive sector, has the power to subvert academic values and autonomy.

We emphasize the need a holistic view which can bring together all possible forms of connections between universities and society. The third mission is carried out through the transfer of technology, but not only; it also involves university extension activities, in all its manifestations and all the possible links that can be thought of and made effective in the future, because it is a concept under construction. Is the third mission an additional source of income? Is it the commercial exploitation of results from academic research? Is it the social outreach of universities? We believe that all these purposes are (and can be) present, because it is a term capable of carrying the most diverse directions and purposes, be they economic, social, cultural, scientific, technological, among others. The activities and scope of commitments, under the title of third mission, will be established and negotiated on a case-by-case basis.

There are several elements or factors that condition the development of the third mission, contributing to its sustainability, as shown in Figure 1.

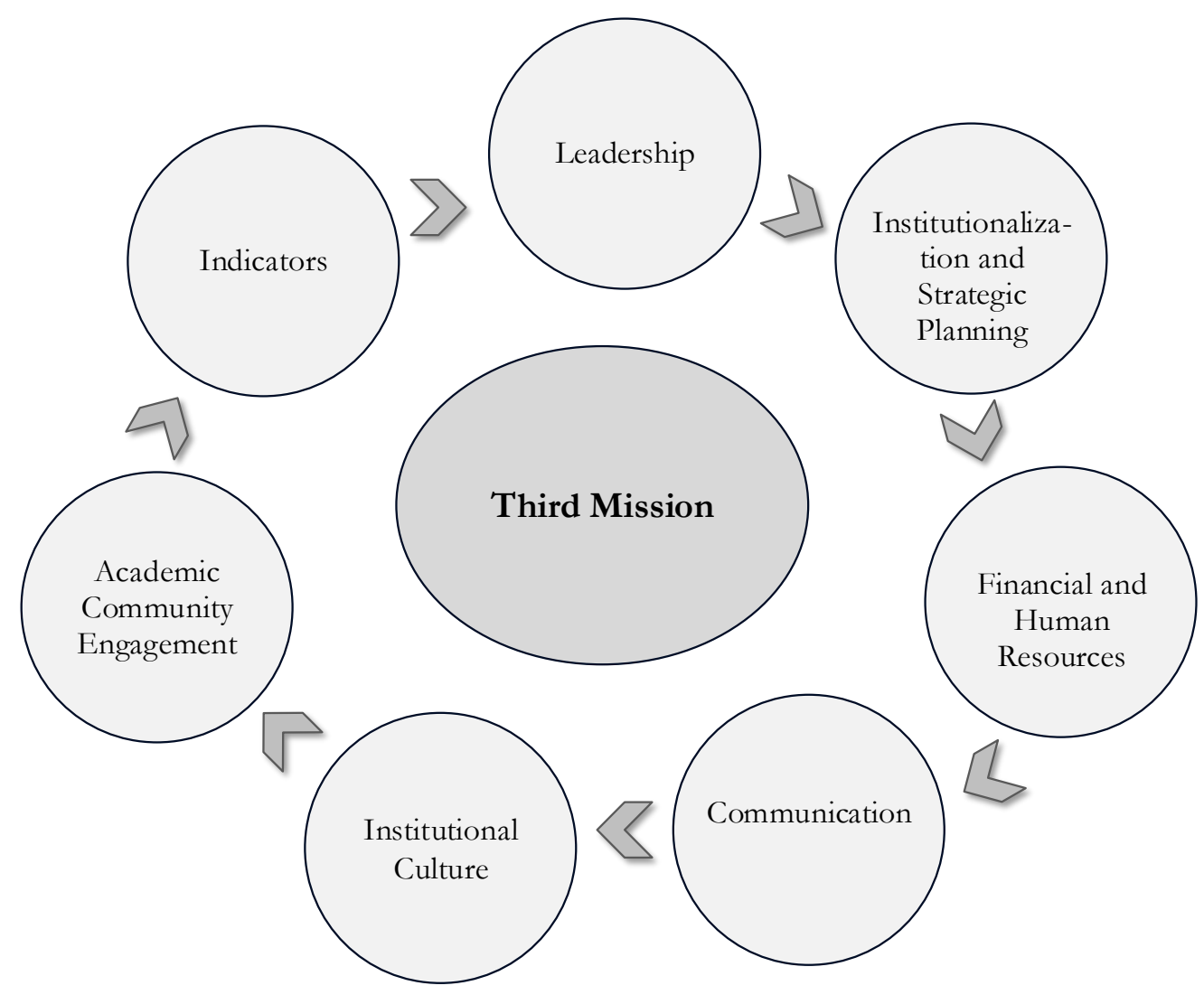

Figure 1. Third Mission Virtuous Cycle

Source: prepared by the authors. 
Universities achieves the third mission when they place their physical and knowledge capacities at the service of society. However, for this to occur and to last, policies stemming from higher management are needed, with the intent of institutionalizing, integrating into strategic planning, providing financial and human resources; communicating/disseminating widely; and fostering a favorable institutional culture, rewarding and encouraging the engagement of the academic community. We reaffirm that engagement presupposes interaction, exchange, sharing, reciprocity, and not only the delivery of knowledge, services or technology. In addition, the creation of indicators for monitoring the third mission may allow policies, strategies and actions to be improved.

The connections between universities and society stem from the social pact between them, and in the twenty-first century it is increasingly expected that the benefits of higher education will reach a larger number of people. It also involves the use and guiding of the capabilities and expertise of universities so that they can act more actively in society, getting involved in and interacting with its surroundings.

\section{References}

Allen, Michael. 1988. The goals of universities. Milton Keynes, UK: SRHE \& Open University Press.

American Society for the Extension of University Teaching. (1891). University extension: its definition, history, system of teaching and organization. Philadelphia. Retrieved from https://archive.org/details/universityextens00ame

Arbo, P., \& Benneworth, P. (2007). Understanding the regional contribution of higher education institutions. OECD Education Working Papers, n. 9, 1-76. Doi: http://dx.doi.org/10.1787/161208155312

Barnes, S. V. (1996). England's civic universities and the triumph of the Oxbridge ideal. History of education quarterly, 36(3), 271-305. Doi: https://doi.org/10.2307/369389

Bernheim, C. T. (1978). El nuevo concepto de extensión universitaria y difusión cultural y su relación con las políticas de desarrollo cultural en América Latina. Anuario de Estudios Centroamericanos, 4, 93-126. Retrieved from https://revistas.ucr.ac.cr/index.php/anuario/article/view/3305

Bernasconi, A. (2008). Is There a Latin American Model of the University? Comparative Education Review, 52, $27-52$. Doi: https://doi.org/10.1086/524305

Bringle, R. G., Hatcher, J. A., \& Holland, B. (2007). Conceptualizing civic engagement: Orchestrating change at a metropolitan university. Metropolitan Universities, 18(3), 57-74. Retrieved from https://scholarworks.iupui.edu/handle/1805/9613

Business/Higher Education Round Table (B-HERT). (June 2006). Universities' third mission: communities engagement. BHERT Position Paper no. 11. Retrieved from https://www.bhert.com/publications/position-papers/BHERTPositionPaper11.pdf

Carnegie Foundation for the Advancement of Teaching. (2013). Carnegie Community Engagement Classification 2015. Retrieved from http://www.fiuc.org/bdf/pdf/carnegie classification-community engag 2015.pdf

Castells, M. (2009). Communication Power. Oxford: Oxford University Press.

Clark, B. R. (1998). Creating entrepreneurial universities: organizational pathways of transformation. Oxford: PergamonElsevier.

Clough, S. (2009). A Study of UK Education Policy in the Adoption and Implementation of Third Stream Activities by Higher Education Institutions. PhD dissertation, Durham University. Retrieved from http://etheses.dur.ac.uk/135/

Conway, C., Humphrey, L., Benneworth, P., Charles, D., \& Younger, P. (2009). Characterising modes of university engagement with wider society: A literature review and survey of best practice. Newcastle upon Tyne: Newcastle University. Retrieved from https://strathprints.strath.ac.uk/48210/ 
D’este, P. C., Castro Martínez, E., \& Molas-Gallart, J. (2014). Documento de base para un Manual de indicadores de vinculación de la universidad con el entorno socioeconómico. (Manual de Valencia). Espanhã: INGENIO (CSICUPV). Retrieved from http://digital.csic.es/handle/10261/132865

Etzkowitz, H., \& Leydesdorff, L. (1997). Introduction: Universities in the Global Knowledge Economy. In Etzkowitz, H. \& Leydesdorff (Orgs). Universities in the Global Knowledge Economy: A Triple Helix of University-IndustryGovernment Relations (pp. 1-8). London: Pinter.

European Indicators and Ranking Methodology for University Third Mission (E3M). (2012a). Needs and constraints analysis of the three dimensions of third mission activities. Retrieved from http://e3mproject.eu/Three-dim-thirdmission-act.pdf

European Indicators and Ranking Methodology for University Third Mission (E3M). (2012b). Green paper: fostering and measuring 'third mission in higher education institutions. Retrieved from http://e3mproject.eu/results.html

Fallis, G. (2005). The Mission of the University. Canadian Society for the Study of Higher Education, 26, 1-24. Retrieved from https://eric.ed.gov/?id=ED535141

Fernández-Larrea, M., \& González, G. R. (2013). ¿Extensión universitaria, proyección social o tercera misión? Una reflexión necessária. Revista Congreso Universidad, 2(2), 1-11. Retrieved from

http://www.congresouniversidad.cu/revista/index.php/rcu/article/view/482.pdf

Fitzgerald, H. E., Bruns, K., Sonka, S. T., Furco, A., \& Swanson, L. (2012). The Centrality of Engagement in Higher Education. Journal of Higher Education Outreach and Engagement, 16(3), 7-27. Retrieved from

http://openjournals.libs.uga.edu/index.php/jheoe/article/view/861

Goddard, J. B.; Kempton, L.; \& P. Vallance. (2013). The civic university: connecting the global and the local. In Capello, R.; Olechnicka, A.; Gorzelak, G. (Eds). Universities, cities and regions: loci for knowledge and innovation creation, (pp. 43-63). Routledge, London/New York.

Gornitzka Åse, and Maassen Peter, Olsen, Johan P., and Stensaker Bjørn. 2007. “Europe of Knowledge:” Search for a New Pact. In Maassen, P., \& Olsen, J. P. (Eds.). University Dynamics and European Integration, (pp. 181-214). Higher Education Dynamics, 19. Springer, Dordrecht. Doi: https://doi.org/10.1007/978-1-4020-5971-1_9

Göransson, Bo, Maharajh, Rasigan, and Schmoch, Ulrich. 2009. New activities of universities in transfer and extension: multiple requirements and manifold solutions, Science and Public Policy, 36(2), 157-164. Doi: https://doi.org/10.3152/030234209X406863

Grao, J., Iriarte, M., Ochoa, C., \& Vieira, M. J. (2014). La Tercera Misión (3M) de las universidades: buenas práticas em la América Latina. México [S.1.]: Imaginarial Editores.

Grau, F. X. (2014). The "Glocal" University. Retrieved from http://www.guninetwork.org/files/glocaluniversity_fx_grau_2014.pdf

Herrera Albrieu, M. L. (2012). Una mirada sobre la extensión universitaria en Argentina. In Cátedra Manuel Ancizar $2012-$ I - Educación Superior y debates para el desafio. Universidad Nacional de Colombia. Retrieved from http://bdigital.unal.edu.co/7472/

Hessels, L. K., Van Lente, H. \& Smits, R. (2009). In search of relevance: the changing contract between science and society. Science and Public Policy, 36(5): 387-401. Doi: https://doi.org/10.3152/030234209X442034

Inzelt, A., Laredo, P., Sanchez, P., Marian, M., Vigano, F., \& Carayol, N. (2006). Third Mission. In Strategic Management of University Research Activities, Methodological Guide, edited by Schoen Antoine (Ed.), (pp. 7-19). Lugano: PRIME Project 'Observatory of the European University. Retrieved from http://www.enideurope.org/PRIME/documents/OEU_guide.pdf

Jongbloed, B., Enders, J., \& Salerno, C. (2008). Higher education and its communities: Interconnections, interdependencies and a research agenda. Higher Education, 56(3), 303-324. Doi: https://doi.org/10.1007/s10734-008-9128-2

Kellogg Commission on the Future of State and Land-Grant Universities. (1999). Returning to our Roots: the engaged institution. Washington, DC: APLU. Retrieved from http://www.aplu.org/library/returning-to-our-roots-theengaged-institution/file

Kerr, Clark. (2005). Os usos da Universidade. 15th ed. Brasília: UNB.

Mackinder, H. J., \& Sadler, M. (1891). University extension, past, present, and future. London: Cassell. Retrieved from https://archive.org/details/extensionunivers00mackrich 
Maunder, A. H. (1972). Agricultural Extension: a reference manual. FAO: Rome. Retrieved from http://files.eric.ed.gov/fulltext/ED075628.pdf

Minayo, M. C. S. (2009). O desafio da pesquisa social. In Minayo, M. C. S., Deslandes, S. F., \& Gomes, R. Pesquisa social: teoria, método e criatividade, (pp. 9-29). Petrópolis: Vozes.

Molas-Gallart, J. \& Castro-Martínez, E. (2007). Ambiguity and conflict in the development of 'Third Mission' indicators. Research Evaluation, 16(4): 321-330. Doi: https://doi.org/10.3152/095820207X263592

Molas-Gallart, J., Salter, A., Patel, P., Scott A. \& Duran, X. (2002). Measuring third stream activities: Final report to the Russell Group of Universities. SPRU, University of Sussex. Retrieved from https://www.academia.edu/532097/Measuring_third_stream_activities

Mora, J. G. \& Vieira, M. J. (Coord.). (2014). Documento de recomendaciones. El fomento de la "Tercera Misión" en las Instituciones de Educación Superior en América Latina. Conclusiones y recomendaciones para los distintos actores. Retrieved from https://recla.org/wp-content/uploads/2015/01/Documento-de-RecomendacionesVinculaentorno.oct-2014.pdf

Observatorio Iberoamericano de la Ciencia, la Tecnología y la Sociedad (OCTS-OEI) and Red Iberoamericana de Indicadores de Ciencia y Tecnología (RICYT). (2017). Manual Iberoamericano de Indicadores de Vinculación de la Universidad con el Entorno Socioeconómico. Manual de Valencia. Retrieved from http://www.ricyt.org/files/manual_vinculacion.pdf

Pinheiro, R. (2011). In the Region, for the Region? A comparative study of the institutionalisation of the regional mission of universities. Doctoral dissertation, University of Oslo, Faculty of Educational Sciences. Retrieved from

https://www.academia.edu/5494496/In_the_Region_for_the_Region_A_comparative_study_of_the_institutionalisation_of the regional mission of universities $\mathrm{PhD}$ dissertation University of Oslo

Participatory Research in Asia (PRIA), \& University of Victoria. (2015). Institutionalizing community university research partnerships: a user's manual. UNESCO Chair in Community Based Research and Social Responsibility in Higher Education. Retrieved from http://unescochair-cbrsr.org/unesco/pdf/CURP Guidelines.pdf

Public \& Corporate Economic Consultants, \& Centre for Business Research - University of Cambridge. (2009). Evaluation of the effectiveness and role of HEFCE/OSI third stream funding. Issues Paper 2009/15 for HEFCE. Retrieved from https://www.cbr.cam.ac.uk/publications/special-reports/

Rocha, R. M. G. (2001). A Construção do Conceito de Extensão Universitária na América Latina. In Faria, D. S. Construção Conceitual da Extensão Universitária na América Latina, (p. 13-29). Brasília: UNB.

Roper, C. D., \& Hirth, M. A. (2005). A history of change in the third mission of higher education: The evolution of one-way service to interactive engagement. Journal of Higher Education Outreach and Engagement, 10(3): 3-21. Retrieved from http://openjournals.libs.uga.edu/index.php//heoe/article/view/380

Scoponi, L., Dias, F. P. M., Pesce, G., Schmidt, M. A., \& Gzain, M. (2016). Cooperación Académica en Latinoamérica para la Innovación en los Agronegocios. Journal of technology management \& innovation, 11(2), 111-120. Doi: https://doi.org/10.4067/S0718-27242016000200011

Serna Alcántara, G. A. (2007). Misión social y modelos de extensión universitaria: del entusiasmo al desdén. Revista Iberoamericana De Educación, 43(3): 1-7. Retrieved from https://rieoei.org/RIE/article/view/2324

Trencher, G., Yarime, M., McCormick, K. B., Doll, C. H. N. \& Kraines, S. B. (2014). Beyond the third mission: Exploring the emerging university function of co-creation for sustainability. Science and Public Policy, 41(2): 151-179. Doi: https://doi.org/10.1093/scipol/sct044

United States of America. Morrill Act, 1862. (1862). Retrieved from http://memory.loc.gov/cgibin/ampage?collId=1ls1\&fileName=012/lss1012.db\&recNum=534

University of Chicago Library. (2006). Guide to the University of Chicago University Extension Records 1892-1979. Retrieved from https://www.lib.uchicago.edu/ead/rlg/ICU.SPCL.UEXTENSION.pdf

Venditti, M., Reale, E., \& Leydesdorff, Loet. (2013). Disclosure of university research to third parties: a nonmarket perspective on an Italian university. Science and Public Policy, 40(6), 792-800. Doi: https://doi.org/10.1093/scipol/sct027

Welch, E. (1973). The Peripatetic University: Cambridge Local Lectures 1873-1973. London: Cambridge University Press. 